NBER WORKING PAPER SERIES

\title{
THE ADOPTION AND DIFFUSION OF ORGANIZATIONAL INNOVATION: EVIDENCE FOR THE U.S. ECONOMY
}

\author{
Lisa M. Lynch \\ Working Paper 13156 \\ http://www.nber.org/papers/w13156 \\ NATIONAL BUREAU OF ECONOMIC RESEARCH \\ 1050 Massachusetts Avenue \\ Cambridge, MA 02138 \\ June 2007
}

This research was supported in part by the National Science Foundation Program on Innovation and Organizational Change. The research in this paper was conducted while the author was a Census Bureau Associate at the Boston Research Data Center. Research results and conclusions are those of the author and do not necessarily indicate concurrence by the Bureau of the Census. This paper has been screened to ensure that no confidential data are revealed. I would like to thank Sandra Black for her significant collaboration on previous papers using these data. I would also like to thank Fabio Schiantarelli, participants in seminars at Tufts University and Columbia University, and the NBER productivity lunch seminar group for useful comments on an earlier draft. The views expressed herein are those of the author(s) and do not necessarily reflect the views of the National Bureau of Economic Research.

(C) 2007 by Lisa M. Lynch. All rights reserved. Short sections of text, not to exceed two paragraphs, may be quoted without explicit permission provided that full credit, including $\odot$ notice, is given to the source. 
The Adoption and Diffusion of Organizational Innovation: Evidence for the U.S. Economy Lisa M. Lynch

NBER Working Paper No. 13156

June 2007

JEL No. D2,J24,M5,O3

\begin{abstract}
$\underline{\text { ABSTRACT }}$
Using a unique longitudinal representative survey of both manufacturing and non-manufacturing businesses in the United States during the 1990's, I examine the incidence and intensity of organizational innovation and the factors associated with investments in organizational innovation. Past profits tend to be positively associated with organizational innovation. Employers with a more external focus and broader networks to learn about best practices (as proxied by exports, benchmarking, and being part of a multi-establishment firm) are more likely to invest in organizational innovation. Investments in human capital, information technology, R\&D, and physical capital appear to be complementary with investments in organizational innovation. In addition, non-unionized manufacturing plants are more likely to have invested more broadly and intensely in organizational innovation.
\end{abstract}

Lisa M. Lynch

Fletcher School

Tufts University

Medford, MA 02155

and NBER

lisa.lynch@tufts.edu 


\section{Introduction}

The sustained growth in productivity in the United States that began in the mid 1990s continues to surprise and confound economists. Between 1995 and 2006 productivity for nonfarm businesses grew at 2.7 percent and productivity in manufacturing grew at 4 percent per year. This increase in productivity, more than a full percentage point above its average annual growth rate for the period 1970-1995, has been labeled by some as the advent of a "New Economy." How long this trend will last is the subject of much speculation, with economists such as Janet Yellen (2005), President of the Federal Reserve Bank of San Francisco, and Jorgenson, Ho, and Stiroh (2004) projecting that we are now on track to maintain a trend rate of productivity growth of around 2.5 percent per year.

Skeptics of the New Economy phenomenon argue that the growth in productivity through 2005 is simply the result of employers' uncertainty due to rising oil prices and geo-political concerns. These factors make employers push their incumbent workers harder since they are reluctant to hire even though profitability is high. Therefore, once these concerns disappear, there should be a marked increase in hiring and a subsequent fall in productivity growth. Whether you believe this is a permanent change in the growth rate of the productivity of the U.S. or just a temporary phenomenon has significant implications for monetary policy. It is therefore very important to try to understand the underlying dynamics of productivity growth in order to predict its sustainability.

The rise in productivity growth in the second half of the 1990s through the first half of this decade has been attributed in large part to investments in information and 
communication technology. However, a careful examination of the various studies that have attempted to disentangle the contributions of capital deepening, labor quality and total factor productivity to average labor productivity suggests that even after accounting for capital deepening, total factor productivity growth has been a very important determinant of the growth of average labor productivity. Capital deepening contributes almost sixty percent of the growth in average labor productivity but total factor productivity contributes thirty seven percent according to Jorgenson, Ho and Stiroh's (2004) decomposition. Total factor productivity is something of a black box but some of the usual suspects include technology, managerial practices, and measurement error. Jorgenson, Ho and Stiroh (2004) further decompose TFP into IT and non-IT components and conclude that the non-IT components are increasingly important for productivity growth post 1995 . In Black and Lynch $(2004,2005)$ we argue that an additional critical component of TFP is workplace human resource management practices or organizational innovation. We find that during the 1990s changes in organizational innovation may have accounted for as much as 30 percent of output growth in U.S. manufacturing.

While there have been an increasing number of empirical studies that suggest a significant positive association between labor productivity and organizational innovation there has been relatively little research on why some firms decide to invest in organizational innovation and others do not. To address this gap in the literature I use a unique representative survey of US businesses over the 1990s to examine the patterns of adoption of organizational innovation (both incidence and intensity) and factors associated with higher incidence and intensity of organizational innovation. Past profits tend to be positively associated with organizational innovation. Employers with a more 
external focus and broader networks to learn about best practices (as proxied by exports, benchmarking, being part of a multi-establishment firm) are more likely to invest in organizational innovation. Firm investments in human capital, information technology, $\mathrm{R} \& \mathrm{D}$, and more generally in physical capital appear to be complementary and precede investments in organizational innovation. In addition, non-unionized manufacturing plants are more likely to have invested more broadly and intensely in organizational innovation.

The next two sections of the paper present a working definition of organizational innovation and summarize the theoretical and empirical literature on the adoption and diffusion of workplace practices and organizational innovation. Section 4 provides some background discussion on the unique data that are used for this study and section 5 presents empirical findings on the incidence and diffusion of organizational innovation. Section 5 examines not only the patterns of incidence and diffusion over the 1990s but also the factors associated with such adoption and diffusion. The final section of the paper considers the implications of the main findings of the paper for our understanding of future productivity growth trends.

\section{A Working Definition of Organizational Innovation}

The challenge with studying organizational innovation (or for that matter any other type of intangible asset) is that there is no clear definition of what organizational innovation is, how to measure it, or how to best quantify its contribution to output (either current or future). Unlike physical capital, the value of organizational capital (and its change) does not appear on the balance sheet of a firm, and when firms undertake 
substantial organizational change or re-engineering this is typically treated as "consumption" rather than an increase in the assets of a firm.

Since the 1990s the European Union has been conducting every 4 years the Community Innovation Survey (CIS) to monitor Europe's progress in the area of innovation. In 2004 the European Statistical Agency EUROSTAT began supplementing its questions on product and process innovation in the CIS with questions on organizational innovation. In the CIS organizational innovation is broadly defined as changes in firm structure or management methods that are intended to improve a firm's use of knowledge, the quality of goods and services, or the efficiency of work flows. In Black and Lynch (2005) we propose a more specific working definition of organizational innovation for U.S. firms that includes the following components - workforce training, employee voice, work design (including the use of cross-functional production processes), and shared rewards. This is not meant to be an exhaustive list of all dimensions of organizational innovation, rather a range of practices that have been found to significantly enhance the productive capacity of a firm.

Workforce training is most commonly undertaken to improve a firm's use of knowledge, quality of goods and services and the efficiency of work flows. As new technology is introduced, training demands of a firm are likely to rise. In addition, as team work becomes more important workers need to acquire additional skills to help them function in a more interactive group environment. How one measures training investments is critical for examining its impact on economic outcomes such as productivity. Simple incidence measures such as yes and no answers to the question whether a firm conducts any formal training programs for employees are unlikely to 
capture adequately organizational innovation. Instead measures such as the proportion of workers trained, hours of training, and types of training programs offered do a better job of capturing the intensity of training investments by employers.

The ability to tap into knowledge of non-managerial workers is an important feature of organizational innovation. This can be done by measuring a second component of organizational innovation -- "employee voice”. By this I mean those organizational structures that give workers, especially non-managerial workers, input into the decisionmaking associated with the design of the production process and greater autonomy and discretion in the structure of their work. Traditional forms of work organization are very task-specific; each production worker has a specific task to complete, and once they learn how to accomplish the task, there is little independent thought involved. However, newer forms of organization involve giving employees, specifically non-managerial workers, more input into the production process and greater opportunities to improve efficiency. The argument that worker voice can increase productivity is consistent with the theoretical discussion presented in Freeman and Lazear (1995). In empirical work researchers have included as measures of this dimension of organizational innovation items such as whether or not a workplace is unionized, whether the firm has a works council, the proportion of workers meeting on a regular basis to discuss workplace issues, the use of total quality management systems, and the proportion of workers in selfmanaged teams.

In Black and Lynch (2005) we discuss a third component of organizational innovation -- work design, that includes the use of cross-functional production processes that result in more decentralized and flexible allocation of labor in the firm. Examples 
include reengineering efforts that may involve changing the occupational structure of the workplace (including increasing the number of technical workers), the number of workers per supervisor, the number of levels of management within the firm, the existence and diffusion of job rotation, and job share arrangements. We also include in this component methods by which firms monitor their practices relative to others such as benchmarking.

Finally, while it is not a type of organizational innovation per se, shared rewards such as profit sharing and stock options play an important role in organizational innovation. These types of payments can realign workers' interests towards those of shareholders. When workers are asked to come forward with ideas that would improve the production process but may also put their own jobs at risk, they must be given an incentive to do this. This can take the form of increased pay and/or more employment (as opposed to job) security. Boning, Ichniowski, and Shaw (2001) have found strong evidence of complementarities between employee voice and incentive pay. Kandel and Lazear (1992) argue that introducing a profit-sharing plan for all workers in a firm may have little or no impact on productivity unless it is linked with other workplace practices. So while incentive based pay in the form of shared rewards is not organizational innovation per se, it may act as glue that holds organizational innovation together.

Theoretically organizational innovation is best thought of as a continuous variable. However, there is no single measure that empirically will capture the full extent of organizational innovation within a firm. It is not surprising, therefore, that researchers have used a wide array of indicators to capture organizational innovation. Some have simply counted up the number of particular workplace practices while others have used factor analysis to construct indices of organizational innovation. However, just adding up 
practices may miss important synergies in organizational innovation as Milgrom and Roberts (1995) have argued. Athey and Stern (1998) discuss how the existence of complementarity in workplace practices implies that the adoption of one practice has externalities for the adoption of other practices. In addition, if practices are adopted in clusters, then some combinations of practices may occur only infrequently making it difficult, empirically, to precisely estimate the impact of each practice on outcomes such as productivity.

Although there is no consensus on how to operationalize the measurement of organizational innovation, there are numerous studies that have established a significant relationship between various measures of such innovation and performance (see Ichniowski and Shaw (2003) for a thorough review of this literature). Most of the studies using data from intra-industry studies and nationally representative surveys ${ }^{1}$ conclude that the adoption of a coherent system of new human resource management practices such as flexible job definitions, cross-training, and work teams, along with extensive reliance on incentive pay, results in substantially higher levels of productivity than more traditional human resource management practices. Many of these studies have also found evidence of the existence of synergies among workplace practices: the total impact is greater than the sum of the parts.

In spite of the large impact organizational innovation appears to have on productivity, we need to ask: if this is so good why isn't everyone doing it or doing more of it? Moreover, have we really captured the impact of organizational innovation on

\footnotetext{
${ }^{1}$ Examples of intra-industry studies include Ichniowski, Shaw and Prennushi (1995), Arthur (1994), Kelley (1994 and 1996), Bailey (1993), and Dunlop and Weil (1996). Research using nationally representative surveys of firms includes Black and Lynch (2001, 2004), Bartel (1994), Bresnahan, Brynjolfsson, and Hitt (2002), Caroli and Van Reenen (2001), Ichniowski (1990), Huselid (1995), Huselid and Becker (1996), and Delaney and Huselid (1996).
} 
productivity or is there something we have missed about the firms that adopt

organizational innovation that is really driving the economic outcomes we are interested in? Understanding the adoption and diffusion of organizational innovation, therefore, is critical for our ability to predict the sustainability of productivity gains obtained through this type of innovation.

\section{Factors Associated with Organizational Innovation}

There have been very few studies that have examined the range of factors associated with the adoption and diffusion of organizational innovation. Some exceptions include Osterman (1994) and Blasi and Kruse 2006 using nationally representative data on U.S. employers, and Ichniowski and Shaw (1995), Pil and MacDuffie (1996), Nickell, Nicolitsas and Patterson (2001), and Chi, Freeman and Kleiner (2007) using survey data on much smaller samples of employers that were restricted to specific geographic locations or industrial sectors. The only dimension of organizational innovation where there has been relatively more analysis of the factors associated with adoption and diffusion is employer provided training. As summarized in Lynch (1994) and Lynch and Black (1998) investments in worker training are higher in larger firms and businesses that have also invested in physical capital and human capital.

Osterman (1994), Ichniowski and Shaw (1995) (for the steel industry) and Chi, Freeman and Kleiner (for a small panel of manufacturing firms close to Minneapolis) all found that younger businesses were more likely to adopt workplace innovations. Younger firms have not had time to build up entrenched management and practices that would be threatened by the adoption or diffusion of organizational innovation. In addition, Osterman (1994) and Chi et. al. (2007) found that small businesses and those with business 
strategies that focused on giving employees more autonomy or who believed that they had a responsibility for employee welfare were more likely to introduce employee involvement programs, have a total quality management program or quality circles, or use teams.

Institutionally unions have traditionally been the primary channel for worker voice. The presence of a union in an organization that wants to undertake more organizational innovation can be very beneficial. Workers in unionized businesses may be more willing to participate in employee involvement programs since they feel the union will protect their overall employment security. However, Freeman and Rogers (1999) found that workers' desire to unionize decreases if the firm they are employed in has in place employee involvement programs so that they feel they have some voice in the firm. In addition, unions may view the introduction of alternative channels for worker voice as a challenge to their authority and a way to limit their power and influence. So the relationship between unionization and work practices that increase employee involvement in decision making is not clear a priori. Chi et. al. (2007) and Ichniowski and Shaw (1995) find a negative association between unionization and likelihood of introducing an employee involvement program whereas Osterman (1994) finds no impact. Interestingly Chi et. al. (2007) find that once introduced, unionized firms are less likely to terminate such programs. Most studies of the adoption of workplace innovations have not had data on past profitability of the business. However, Pil and MacDuffie (1996) in their international study of the auto industry find some weak support for the hypothesis that worst performing plants are more likely to introduce workplace reorganization. Nickell et. al. (2001) also find evidence for a small sample of U.K. firms in the 1980s that businesses are more likely to invest more in reorganization when the 
real output price or productivity is declining. Declining performance may be due to increased competition both domestically and internationally. Osterman (1994) and Blasi and Kruse (2006) (using data from the same survey used in this paper) find that firms in industries with higher exports more likely to innovate. However the Blasi Kruse (2006) analysis is done only at the industry group level and includes a limited number of other controls - firm size and union status.

Finally, some of the changes we see in work design are associated with the introduction and diffusion of information technologies within the firm. For example, email facilitates greater communication between and across workers, both managerial and non-managerial. Brynjolfsson, Hitt and Yang, (2002) and Bresnahan, Brynjolfsson, and Hitt (2002) have argued that technical change and organizational change are complementary activities. So investments in information technology and other types of capital may facilitate organizational innovation.

Ideally any examination of the adoption, diffusion and termination of investments in organizational innovation should be done on a representative sample of businesses over time and control for profitability, capital investments including investments in IT, product market competition, management quality, unionization, and characteristics of workers. Due to data limitations no previous study has done this. This study addresses this gap in the literature. Using longitudinal data from a unique nationally representative survey of businesses I am able to examine a wide range of factors and their association with the adoption and diffusion of organizational innovation. My analysis focuses on five main research issues. The first is the role of past profitability in the decision to undertake current or future investment in organizational innovation. On the one hand it 
may be the case that those businesses that have been doing poorly in the past may have a greater need to change and may find it is easier to get employee buy-in to dramatically reorganize work in a time of crisis. On the other hand, organizational innovation is a costly investment so the firms most likely to adopt and invest extensively in organizational innovation are those who can afford to do so.

The second issue I examine is the role of external focus and networks in the adoption and diffusion of organizational innovation. It may well be the case that those businesses that export a higher fraction of their output, use benchmarking and are part of a multi-establishment firm are more likely to invest in organizational innovation.

The third issue is the complementarity between investments in information technology and organizational innovation. While it has been hypothesized that such a complementarity exists, having information on past as well as current investments in IT and organizational innovation is critical to examine sequencing of investment.

Fourth, those businesses with greater internal capacity to take advantage of organizational innovation (i.e. more educated employees and more employees with "softer" skills such as communication) are more to adopt and have higher diffusion of organizational innovation than employers with less skilled workforces.

Finally, there will be forces that will either resist or be in favor of organizational change. I investigate whether older businesses, since they are more likely to have entrenched management, are less likely to introduce such changes. The effect of a union is ambiguous. On the one hand some unions may oppose organizational change because it is perceived as leading to a loss of union power. On the other hand, the presence of a union may lead workers to more willingly participate in new work practices because they 
feel that their employment is more secure. Moreover, managers in non-unionized plants may favor adopting these practices as a way to reduce the probability of a plant becoming unionized. Finally, certain occupational groups may be relatively more in favor of such investment - technical workers, while others may be more opposed because it challenges their traditional authority - supervisors.

\section{Data}

The data used in this paper come from the Educational Quality of the Workforce National Employers Survey, EQW-NES. The first round of the EQW-NES was administered by the U.S. Bureau of the Census as a telephone survey in August and September 1994 to a nationally representative sample of more than 3,000 private establishments with more than 20 employees ${ }^{2}$. The respondents were asked to provide data for the previous year. The survey represents a unique source of information on how employers recruit workers, organize work, invest in physical capital, and utilize education and training investments. The survey over-sampled establishments in the manufacturing sector and establishments with more than 100 employees. Public sector employees, notfor-profit institutions, and corporate headquarters were excluded from the sample. The target respondent in the manufacturing sector was the plant manager and in the nonmanufacturing sector was the local business site manager. However, the survey was designed to allow for multiple respondents so that information could be obtained from establishments that kept financial information such as the book value of capital or the

\footnotetext{
2 The first survey was designed by Lisa Lynch in collaboration with EQW Co-Directors Robert Zemsky and Peter Cappelli. The second survey included a subset of questions identical to this first round plus an extensive section on employers' school-to-work activities. The surveys were supported by the Office of Educational Research and Improvement, US Department of Education.
} 
cost of goods and materials used in production at a separate finance office (typically at corporate headquarters for multi-establishment enterprises). The sample frame for the survey was the Bureau of the Census SSEL file, one of the most comprehensive and upto-date listings of establishments in the United States. Although the sampling frame omits establishments with less than 20 employees, it captures establishments that employ approximately three-quarters of all workers in the U.S.

The response rate in the first round EQW National Employers Survey for manufacturing and non-manufacturing establishments was 72 percent. This is substantially higher than most other voluntary establishment surveys. However, not all of the establishments who participated in the survey completed all parts of the survey by the interview cutoff date of October 1, 1994. Therefore, the final number of establishments in the sample for which all parts of the survey were completed was 3167, a slightly lower 63 percent 'completed' survey response rate.

A second survey was administered by the Census Bureau in August 1997 with a response rate of 78 percent $^{3}$. The final sample for the second round of the EQW-NES included 3081 establishments -- 1827 in the manufacturing and 1254 in the nonmanufacturing sector. The second survey was considerably longer in duration than the first survey (close to 45 minutes). Therefore, in spite of the high overall response rate there are a large number of businesses that do not provide information on all questions asked including items such as the value of shipments and sales, the book value of the capital stock, the costs of materials, wages paid to workers and the proportion of workers trained. This will reduce the final sample sizes used for analysis in this paper.

\footnotetext{
${ }^{3}$ There was oversampling of establishments in California, Kentucky, Michigan, Maryland and Pennsylvania and a sub sample of establishments that had been contacted in the first round.
} 
A panel of 766 establishments (approximately two-thirds of which were manufacturing establishments) can be constructed from the two rounds of the EQW-NES. The panel response rate (for first round establishments who were contacted and completed the interview in the second round) was 74 percent. The EWQ-NES was designed so that a large fraction of the manufacturing establishments could be matched with the Census Bureau's Longitudinal Research Database, the LRD, which pools information from the Annual Survey of Manufacturers and the Census of Manufacturers. In this paper I will use data on sales, capital expenditures, employment, and material and labor costs to construct measures of operating profits per worker and investment per worker.

\section{Empirical Results}

Using the unique data described above this section presents detailed findings on the incidence and extent of organizational innovation and the factors associated with the adoption and diffusion of organizational innovation during the 1990s. The empirical work is organized as follows. Descriptive statistics on the incidence and intensity of organizational innovation for manufacturing and non-manufacturing businesses are presented first. A cross section and longitudinal analysis of the factors associated with organizational innovation in the manufacturing sector follows. Finally, I conclude with the empirical analysis of the factors associated with organizational innovation for the non-manufacturing sector.

Description of Practices. Table 1 presents some descriptive statistics on the incidence and intensity of various dimensions of organizational innovation. While the EQW-NES survey has information on a lengthy list of workplace practices, I focus on 
those that have been the most significant in previous work on determinants of productivity and wages (see Black and Lynch $(1996,2001,2004)$ ). These include the proportion of production workers receiving training, the proportion of non-managerial workers meeting regularly to discuss workplace issues, the fraction of workers in selfmanaged teams, and the proportion of workers who participate in job rotation. For each of these practices I also construct an incidence measure that equals 1 if any fraction of the workforce participates in the practice and zero otherwise. In addition, the 1997 survey included a question on whether or not the establishment underwent any re-engineering over the past three years. Re-engineering production is a radical change in the organizational structure of a company and usually means moving away from highly specialized and compartmentalized departments to more cross-functional teams that follow a product through from development to final distribution. Since this is such a major disruption to the production process it is not surprising that the survey finds only a relatively small fraction underwent this massive organizational change -12 percent of manufacturing establishments and 9 percent of non-manufacturing establishments over the period 1994-1997.

The two practices with the highest incidence include production worker training and the percentage of non-managerial workers meeting on a regular basis to discuss workplace issues. Over 80 percent of manufacturing and non-manufacturing establishments provided training for production workers in 1994 and more than threequarters of all businesses reported having some non-managerial workers meeting regularly to discuss workplace issues. However, less than one half of all employers use job rotation and slightly less than one third of employers report having self-managed 
teams. Manufacturing establishments report a higher incidence of usage of job rotation while non-manufacturing establishments report a higher incidence of employer provided training for non-managerial workers. Interestingly there has not been an across the board increase in the incidence of the practices associated with organizational innovation over the period of 1994 to 1997. In fact, in several of the dimensions of organizational innovation examined in this survey we see the incidence actually declining by 1997 . This suggests that there is experimentation in practices going on and some firms reducing or even terminating programs such as allowing employees to work in self-managed teams.

The effect of organizational innovation on the productive capacity of a firm will depend not only upon the incidence but also upon the extent of investments in such innovation. In Table 1 we see that while almost half of all manufacturing establishments report having job rotation on average, only 23.7 percent of workers rotated their jobs. Approximately 30 percent of all establishments report having some workers in selfmanaged teams yet the extent of workers in self-managed teams is much lower. Over the period 1994-1997 the fraction of workers in manufacturing receiving training remained relatively constant around one half, while the fraction rose in non-manufacturing from slightly less than half of all workers to two thirds of all workers. While the percentage of employers with workers meeting on a regular basis to discuss workplace issues declined over this time period, the percentage of workers meeting regularly increased. So the decline (from a high level) of the incidence of this practice across employers is paralleled by more extensive employee participation within those firms who did have regular meetings with workers. 
One of the reasons for the high response rate to this survey was a keen interest by the respondents (plant and business site managers) to find out what worked and what others were doing in this area of innovation. This suggests that there may have been experimentation with different practices. Table 2 shows the percentage of business that changed their investments in organizational innovation $(+/-5$ percent or more from their 1994 level) over the period 1994-1997. There was a great deal of change in the fraction of workers trained and the fraction of workers meeting regularly. In general the trend was to increase this practice but there were firms that reduced their activities in these areas. In addition, the extent of job rotation and workers in self-managed teams seems to have stalled at relatively low levels, especially in non-manufacturing. In Black and Lynch (2004) we found that those manufacturing employers with a higher fraction of their production workers in self-managed teams had lower productivity, everything else constant. So the fact that we do not see more diffusion of this practice likely reflects managerial experience of lower productivity gains associated with this practice compared to others.

Figure 1 shows the distribution of practices in 1997 across our survey for the manufacturing and non-manufacturing sectors. More manufacturing establishments (70 percent) had three or more practices than non-manufacturing businesses (65 percent). After controlling for the intensity of usage of the practice (only counting a practice if the percentage of workers engaged in it is above the mean for that practice) we see in the bottom half of this figure that only forty percent of manufacturing and thirty-eight percent of non-manufacturing businesses have intensely invested in these practices. So while this figure indicates that a high fraction of employers report that they are 
innovating on these dimensions, there is still room for more intensive adoption of these practices within firms.

\section{Organizational Innovation in Manufacturing: Cross Section Results. I have} separated the sample into manufacturing and non-manufacturing because for the manufacturing sector I am able to match the survey information on organizational innovation with data from the Census Bureau's longitudinal research database, the LRD. Table 3 presents results from probit models of the factors associated with the probability of having each specific dimension of organizational innovation. The dependent variables have a value of 0 or 1 simply indicating whether or not establishment has invested at all in the specific practice at two different points in time - 1994 and 1997. I estimate a separate equation for each survey year.

The explanatory variables are grouped into five categories - external focus variables, technology, profitability, skill capacity and other establishment characteristics. For measures of external focus I include whether or not the establishment is part of a multi-establishment firm, the percentage of the main product that is exported ${ }^{4}$, and whether or not the establishment benchmarks its practices to other organizations. To capture IT technology I include the percentage of non-managerial workers who use computers in their job. Since I am able to match many of the manufacturing businesses in the EQW survey with the Census Bureau's LRD I can construct the average annual investment per worker and the average annual operating profit per worker over the six years prior to the reference year for the measure of organizational innovation (see the appendix for more details on both of these variables). This allows me to examine how past profits and investments correlate with present investments in organizational

\footnotetext{
${ }^{4}$ Missing data on exports in the EQW-NES survey is supplemented with data from the Census LRD.
} 
innovation. By using average values on investment and profitability I smooth year to year fluctuations. Moreover, using six years allows me to maximize the number of Economic Censuses (conducted every five years) used in the construction of the variables. For 1994, I am also able to include whether or not the business had any R\&D activities either at its own site or at another establishment within the firm.

Using information from the EQW survey I construct two measures of skills capacity of the establishment. The first is the average education of workers in the establishment using information on average education in the establishment for 5 occupational categories and the employment share for each of these occupations within the establishment as weights. The second measure is a $0-1$ indicator of whether or not communication skills are a high priority in recruitment by the employer. Other establishment characteristics controlled for include whether or not the establishment is unionized, the age of the establishment, the total number of workers, the share of workers by occupational category, the fraction of employees who are female or minority, and industry controls. Unfortunately questions on age of the establishment and R\&D activity were only asked in the 1994 survey so I am not able to include these measures in the 1997 equation.

In general we see in Table 3 that firms that have a more "external" focus are more likely to have adopted some types of organizational innovation. However, the magnitude of the association between these external factors and the different dimensions of organizational innovation is not uniform. Being part of a multi-establishment firm is positively associated with adopting several dimensions of organizational innovation while the share of production exported is actually associated with a lower probability of 
training production workers. In addition, those businesses that have a larger fraction of their non-managerial workers using computers in their job or invest in R\&D are more likely to train, have workers meeting on a regular basis to discuss workplace issues, or have some workers organized in self-managed teams. Lagged capital investments per worker (that include IT and non-IT related capital) are positively associated with having workers meeting regularly but negatively associated with having job rotation in 1997.

We see little association between profits and most dimensions of innovation in Table 3. The one exception is the positive association between past profits and having workers meet regularly to discuss workplace issues. In terms of skill capacity, those establishments with more educated employees and employees with more effective communication skills are also more likely to have adopted various dimensions of organizational innovation.

The impact of unions on organizational innovation is mixed. On some dimensions such as shared rewards and training, the presence of a union increases the probability of there being this type of workplace innovation. However, non-unionized firms are more likely to have job rotation and non-managerial workers meeting regularly. This is in spite of the fact that in Black and Lynch (2004) we found that unionized establishments that have workers meeting on a regular basis have significantly higher productivity than otherwise similar non-unionized establishments.

Finally, larger employers and those establishments with a higher fraction of production workers are more likely to adopt these practices than smaller employers. Interestingly, age of the establishment does not seem to be a factor in adoption of organizational innovation after controlling for other characteristics of the establishment. 
Table 4 examines a different margin of organizational innovation - the diffusion of specific practices within an establishment ${ }^{5}$. Those employers that benchmark their processes with other firms are more likely to have a higher fraction of their workers engaged in job rotation, in training, meeting regularly to discuss workplace issues and in self-managed teams. In addition, businesses that have been more profitable in the past or that have a higher fraction of their workers using computers in their jobs are likely to have a higher fraction of their workforce meeting regularly or in self-managed teams. Engaging in R\&D and having a more skilled workforce is also positively associated with intensive use of most of the dimensions of organizational innovation. However, older and unionized establishments are likely to have a lower diffusion rate of these workplace practices. Finally, the association between lagged capital investment per worker and organizational innovation seems to vary by practice and over time.

The previous two tables have examined each of the dimensions of organizational innovation separately. In Table 5 I allow for complementarities and synergies in these practices and examine first the factors associated with undertaking a significantly large organizational innovation -- re-engineering and then factors associated with different summary measures of the extent of practices within manufacturing establishments. Column one presents estimates from a probit analysis of the probability of a business reengineering their production process over the period 1994-1997 as a function of 1997 characteristics of the establishment. Benchmarking is associated with an increase in the probability of re-engineering, as does being a large firm that is part of a multiestablishment firm. There appears to be complementarity between investments in IT and re-engineering a business. In addition, businesses that have done better in the past with

\footnotetext{
${ }^{5}$ Tobit estimates with cutoffs at 0 and 100 .
} 
respect to profits are more likely to re-engineer. This suggests that deep pockets rather than crisis times are most relevant for undertaking this type of major organizational innovation.

The remaining columns examine various summary measures of the other dimensions of organizational innovation. I first construct a raw count measure that just adds up each of the practices irrespective of how intensely a business has implemented the specific practice. I then re-define count to only include a practice if the fraction of workers engaged in the practice is equal to or greater than the mean for manufacturing. This variable is labeled "count intense" and equations using these two types of measures are estimated using ordered probit models. The final dependent variable is constructed by using principal components analysis to create an index of organizational innovation. Estimation for this dependent variable is done using standard multiple regression analysis.

Regardless of survey year, those establishments that benchmark, have been more profitable in the past, have prioritized recruiting workers with high communication skills, have a higher fraction of production and technical workers, or are non-union are much more likely to have adopted a more comprehensive range of practices associated with organizational innovation. In addition, in 1997 we see that those employers who have invested more in IT and have a more educated workforce are more likely to have invested more broadly in organizational innovation.

In sum, in the cross section analysis it appears that there is some evidence of complementarity in investments in IT and investments in organizational innovation. In addition, non-union businesses that have more educated employees, a greater share of 
production workers, and an external focus are more likely to invest extensively and intensively in organizational innovation. Finally, investments in this type of innovation seem to occur more in businesses that have been doing well in terms of profits rather than in businesses in financial crisis.

Organizational Innovation in Manufacturing: Panel Results. In spite of the wealth of information contained in the EQW-NES survey and the Census data, this analysis may not control for all factors that are associated with organizational innovation. The cross section estimates may still be subject to omitted variable bias due to unobserved establishment characteristics. One can remove biases due to omitted but time-invariant establishment-specific effects using panel data. Table 6 presents fixed effect estimates for changes in the extent of organizational innovation. Two measures for the dependent variable are used - changes in the raw count in practices between 1994 and 1997 and re-engineering (this is a change measure since it equals 1 if the establishment re-engineered at any time during 1994-1997) ${ }^{6}$. The first column of results presents estimates from a standard fixed effect model. The second column treats the change in investment in organizational innovation over the period 1994-1997 as a function of changes in establishment characteristics over this period along with the level of those characteristics in 1994. The introduction of lagged level variables in this first differenced equation is consistent with assuming that the level of practices in 1997 depends both upon the level of an explanatory variable in 1997 and its cumulated value up to 1994.

In equation 1 for both dependent variables we see that those businesses that grew in employment over this period were also more likely to change their investment in

\footnotetext{
${ }^{6}$ This is perhaps a better specification for re-engineering than what was presented in Table 5 column 1 where the explanatory variables are in levels.
} 
organizational innovation. This is potentially an important result since much of the discussion on organizational innovation seems to suggest that this type of change in workplace practices results in a decreased demand for labor.

In Table 6 the coefficient of the change in lagged average profitability is not significant in any equation. It may be that changes in employment are picking up the relative economic health of these establishments or there is actually not enough variation in this average value over this time to pin down its coefficient. Alternatively, profitability in the cross sectional equation may have simply been a proxy for the overall quality of a firm and of its management. Note that while the coefficient on the change in profits is not significant, the lagged level of average profits in 1994 has a negative and significant coefficient in the equation for the change in the count measure between 1994 and 1997, but not in the one for reengineering. Conditional on recent past profitability, lower accumulated profits in the more distant past seem to be associated with organizational innovation further down the road.

Those employers that change their recruitment priorities and hire workers with higher communication skills are also more likely to increase their investment in organizational innovation. In equation 2 we control for the cumulated stock of investments in organizational capital by also including the level of the explanatory variables in 1994 . Now a richer and more complex story emerges about investments in organizational innovation. There appears to be a complementarity between the amount of organizational innovation and investments in IT. Both the level and the change of the percentage of non-managers using computers are positive and significant in equation 2 . 
When we examine equations 3 and 4 in Table 6 we see some differences in the factors associated with changes in the count of practices versus re-engineering. For reengineering, which is perhaps the most extensive and expensive form of organizational innovation, having in place a more educated workforce or being part of a multiestablishment firm resulted in an increased likelihood that the plant re-engineered its production process. Although the fraction of non-managers using computers is never significant, the coefficient on the change in the lagged average investment per worker is positive and significant for re-engineering in equation 4 suggesting complementarities between past investment in all types of physical capital and more recent investments in organizational innovation. Those establishments who were more inward focused in 1994 or had invested in softer skills in their workforce were also more likely to adopt additional dimensions of organizational innovation over the period 1994-1997.

In sum, looking at the results for the cross section and panel equations together we see some evidence, especially in the cross section equations, that those businesses who have had higher past profits are better positioned to undertake investments in organizational innovation. Past profits tend to be positively associated with organizational innovation. Employers with a more external focus and broader networks to learn about best practices (as proxied by exports, benchmarking, being part of a multiestablishment firm, and having a more diverse workforce) are more likely to invest in organizational innovation. The positive association seen in the cross section results between investing in $\mathrm{R} \& \mathrm{D}$ and investing in organizational capital may reflect a broader taste for innovation by management. Investments in human capital, information technology and more generally in physical capital appear to be complementary and 
precede investments in organizational innovation. Plants that have more employees and a higher share of production and technical workers are more likely to adopt and invest more intensively. Finally, non-unionized plants are more likely to have invested more broadly and intensely in most dimensions of organizational innovation.

Due to confidentiality restrictions, I have not been able to report industry coefficients in each of the equations presented. Nevertheless, there are clear patterns which emerge across sub-sectors within manufacturing. Primary and fabricated metals along with establishments in food and tobacco are much more likely to adopt and invest more intensively in the various dimensions of organizational innovation examined here. However, the one industry that consistently has a significantly lower probability of investing is textile and apparel. This final result is perhaps not that surprising given the looming elimination of the Multi-Fiber Agreement facing this industry at the time of these surveys. These results suggest that there are important industry differences in the adoption and diffusion of organizational innovation that would be important to consider in prioritizing sectors for intra-industry research.

Organizational Innovation in the Non-Manufacturing Sector. Tables 7-9 reexamine the factors associated with organizational innovation but now focusing on the non-manufacturing sector. There are clearly important differences between these two broad sectors such as average size of establishment. However, one of the most important differences between these sectors in the EQW-NES surveys has to do with the diffusion of information technology. One in three non-managerial workers in the manufacturing sector uses computers in their jobs while, as shown in Table 7, two-thirds of nonmanagerial workers in non-manufacturing in 1997 use computers in their job. 
Unfortunately it is not possible to match the EQW-NES survey for non-manufacturing establishments with establishment level data from the Census Bureau such as lagged operating profits since these data are not collected at this level of disaggregation by the Census Bureau ${ }^{7}$. Nevertheless we can see how other factors are associated with adoption and diffusion of organizational capital in non-manufacturing establishments. In particular, it will be interesting to see if we see the same associations between investments in human capital and information technology with investments in organizational capital.

Table 7 presents findings on the probability of adopting various components of organizational innovation. As in the results for manufacturing we see that using benchmarks, having a more educated workforce and investing in R\&D is associated with an increase in the probability of adopting several dimensions of organizational innovation. However investments in IT seem to only be positively and significantly associated with training and not any other component. The coefficient for unionization is insignificant with the exception of the probability of having shared rewards in 1994 where it appears with a positive sign. Larger establishments (in terms of employment) are more likely in some years to have shared rewards for non-managerial workers or to have job rotation.

Table 8 contains the results on the diffusion of various dimensions of organizational innovation. We see that investing in R\&D is associated with a higher proportion of workers getting training, a higher fraction of non-managerial workers meeting to discuss workplace issues, and a higher fraction of employees working in self-

\footnotetext{
${ }^{7}$ I also do not include fraction of product exported due to missing data for 1997 that can not be filled in with Census data. However, for 1994 this is never significant for any equations estimated.
} 
managed teams. Unionized establishments have a higher fraction of non-managerial workers receiving training but a lower fraction of workers meeting regularly. For the first time we see the age of establishment coming in significant with younger establishments, as well as smaller establishments, more likely to have a higher diffusion of organizational innovation. In addition we see a positive association between the diffusion of information technology and the fraction of workers meeting to discuss workplace issues in 1994.

In Table 9 I allow for complementarities and synergies in these practices and examine the factors associated with undertaking re-engineering and the number of practices adopted in non-manufacturing establishments. Column one presents probit estimates of the probability of a business re-engineering their production process over the period 1994-1997 as a function of 1997 characteristics of the establishment.

Benchmarking, being part of a multi-establishment firm and having a more educated workforce are all positively associated with undertaking this major organizational innovation.

The remaining columns in Table 9 present results on the degree of investment in organizational innovation by counting the number of practices, only counting practices when they pass a threshold of diffusion, or using an index of organizational innovation as the dependent variable. In general we see that establishments with a more external focus as proxied by benchmarking or being part of a multi-establishment firm are more likely to have undertaken multiple dimensions of organizational innovation. Those establishments with more educated workers and who have invested more in IT are also more likely to 
have invested in multiple components of organizational innovation. Unionization is never significant nor is size of establishment except in 1994 for the index of practices.

Finally, while I can not report specific coefficients I can summarize the relationships between sub sectors in non-manufacturing and different dimensions of organizational innovation. In general the sub sector that is more likely to invest in various dimensions of organizational innovation even after controlling for a broad range of other factors is the wholesale trade sector. Not surprisingly, the likelihood of workers working in self-managed teams is greater in the construction industry and less in financial services. Workers in the communications and utilities sectors are more likely to be in job rotation and those in business services are more likely to receive employer provided training. These results highlight the importance of including a wider range of controls when trying to examine the relationship between industry and organizational innovation. They also suggest so additional sectors to be studied in more detail in the nonmanufacturing sector.

\section{Conclusion}

The latest measures of productivity growth for 2006 suggest a slowdown in growth from the previous decade. Does this mean that the so-called "New Economy" has returned to the "Same-Old Economy"? The answer will depend in large part on the investments companies will make in innovation - both technological and organizational. This paper has provided evidence to suggest that at least in terms of investments in organizational innovation there are several factors that seem to be highly correlated with this type of innovation. These include having a skilled workforce, higher past operating 
profits, significant past investments in information technology, an external focus on the part of management, and being a relatively young and non-unionized business.

With an increasingly global economy it is likely that U.S. managers are going to continue to be more outwardly focused. Profit rates are at historical highs so businesses certainly have the financial resources to invest in organizational innovation. However, since the later part of 2006 business investment in equipment and software has slowed sharply. This may have negative consequences on productivity growth directly and indirectly due to the complementarity between IT and organizational innovation. Unionization in the private sector in the U.S. continues to decline so we might expect to see more investment by non-unionized employers in organizational innovation. However, as discussed in Black and Lynch 2004 and 2001, those unionized establishments that also invest in organizational innovation have significantly higher productivity than similar non-unionized establishments. Therefore, the impact of this decline in unionization on productivity may be mixed.

An important factor that facilitates investments in organizational innovation is the skill level of our workforce. This is a potential area of concern. From the OECD International Adult Literacy Survey we know that only half of the U.S. adult population aged 16-65 years of age has the minimum proficiency necessary, as identified by the National Institute for Literacy, to succeed in the labor market. From one in five to as many as one in four U.S. adults scored in the lowest category for the three literacy areas that were tested -- prose, document, and quantitative literacy. Given this skills gap, firms that would like to invest in organizational innovation may find themselves constrained by skills shortages in our economy. 
The final factor associated with more organizational innovation is the age of establishment, in particular for the non-manufacturing sector. The bad news here is that we do not know much about these firms. Our business statistics have not kept up with the changing nature of our economy ${ }^{8}$. Not only do they not track important forms of intangible capital such as organizational innovation that have played an increasingly important role in productivity growth in recent years, they also provide limited coverage of new young businesses. Census data limitations also mean that we are not able to examine the relationship between past profits and innovation in the non-manufacturing sector as we are able to do for manufacturing. Addressing these data limitations would be enormously helpful to researchers and policy makers alike so that they may better understand the role of all types of innovation for the U.S. economy.

\footnotetext{
${ }^{8}$ See Haltiwanger, Lynch and Mackie (2007) for more discussion on these data gaps.
} 


\section{$\underline{\text { References: }}$}

Arthur, Jeffrey. 1994. "Effects of Human Resource Systems on Manufacturing Performance and Turnover." Academy of Management Journal vol. 37, pp.67087.

Athey, Susan and Scott Stern. 1998. "An Empirical Framework for Testing Theories About Complementarity in Organizational Design”, NBER working paper 6600.

Bailey, Thomas. 1993. "Organizational Innovation in the Apparel Industry.” Industrial Relations, vol. 32, pp. 30-48.

Bartel, Ann. 1994. "Productivity Gains from the Implementation of Employee Training Programs," Industrial Relations, Volume 33, Number 4, October.

Black, Sandra E. and Lisa M. Lynch. 2005. "Measuring Organizational Capital in the New Economy", in Carol Corrado, John Haltiwanger and Dan Sichel, editors, Measuring Capital in the New Economy, University of Chicago Press.

Black, Sandra E. and Lisa M. Lynch. 2004. "What's Driving the New Economy? The Benefits of Workplace Innovation", The Economic Journal, vol. 114, February, pp. 97-116.

Black, Sandra E. and Lisa M. Lynch. 2001. "How to Compete: The Impact of Workplace Practices and Information Technology on Productivity", Review of Economics and Statistics, August.

Black, Sandra and Lisa M. Lynch. 1996. "Human Capital Investments and Productivity", American Economic Review, May.

Blasi, Joseph and Douglas Kruse. 2006. "U.S. High-Performance Work Practices at Century's End.” Industrial Relations, p.547-578.

Boning, Brent, Casey Ichniowski, and Kathryn Shaw. 2001. "Opportunity Counts: Teams and the Effectiveness of Production Incentives," NBER working paper 8306, May.

Bresnahan, Timothy F., Erik Brynjolfsson, and Lorin M. Hitt. 2002. "Information Technology, Workplace Organization, and the Demand for Skilled Labor: FirmLevel Evidence," The Quarterly Journal of Economics, February, pp. 339-376. 
Brynjolfsson, E, L. Hitt and S. Yang. 2002. "Intangible Assets: Computers and Organizational Capital" Brookings Papers on Economic Activity, Brookings Institution.

Caroli, Eve and John Van Reenen. 2001. "Skill-Biased Organizational Change? Evidence from a Panel of British and French Establishments," The Quarterly Journal of Economics, vol. 116, pp 1449-1492.

Chi, Wei, Richard B. Freeman and Morris M. Kleiner. 2007. "Adoption and Termination of Employee Involvement Programs," NBER working paper 12878.

Delany, John and Mark Huselid. 1996. "The Impact of Human Resource Management Practices on Perceptions of Performance in For-Profit and Nonprofit Organizations," Academy of Management Journal, pp. 949-969.

Dunlop, John and David Weil. 1996. "Diffusion and Performance of Modular Production in the U.S. Apparel Industry," Industrial Relations, vol. 35, July, pp.334-354.

Freeman, Richard and Edward Lazear. 1995. "An Economic Analysis of Works Councils" in Joel Rogers and Wolfgang Streeck, eds. Works Councils, Chicago: The University of Chicago Press.

Haltiwanger, John, Lisa M. Lynch and Christopher Mackie, editors. 2007. Understanding Business Dynamic: An Integrated Data System for America's Future. The National Academies Press.

Hughes, Alan and Michael Scott Morton. 2005. ICT and Productivity Growth - The Paradox Resolved? MIT Sloan School working paper 4579-05, November.

Huselid, Mark A. 1995. "The Impact of Human Resource Management Practices on Turnover, Productivity, and Corporate Financial Performance." Academy of Management Journal, Vol. 38 No.3, pp. 635-672.

and Brian E. Becker. 1996. "High Performance Work Systems and Firm Performance: Cross-Sectional Versus Panel Results." Industrial Relations, vol. 35, pp. 400-422.

Ichniowski, Casey 1990. "Human Resource Management Systems and the Performance of U.S. Manufacturing Businesses." NBER Working Paper 3449, September.

Ichniowski, Casey and Kathryn Shaw. 1995. "Old Dogs and New Tricks: Determinants of the Adoption of Productivity-Enhancing Work Practices." Brookings Papers on Economic Activity: Microeconomics.

Ichniowski, Casey and Kathryn Shaw. 2003. "Beyond Incentive Pay: Insiders' Estimates of the Value of Complementary Human Resource Management Practices." The Journal of Economic Perspectives, vol. 17(1), pp. 155-178. 
Ichniowski, Casey, Kathryn Shaw, and Gabrielle Prennushi. 1997. "The Effects of Human Resource Management Practices on Productivity." American Economic Review, vol. 87(3), pp. 291-313.

Jorgenson, Dale M., Mun S. Ho, and Kevin J. Stiroh. 2004. "Will the U.S. Productivity Resurgence Continue?" Current Issues in Economics and Finance, Federal Reserve Bank of New York, December.

Kandel, E. and Edward Lazear. 1992. "Peer Pressure and Partnerships.” Journal of Political Economy. Vol. 100, pp. 801-817.

Kelley, Maryellen. 1994. "Information Technology and Productivity: The Elusive Connection." Management Science, vol. 40, pp. 1406-25. . 1996. "Participative Bureaucracy and Productivity in the Machined Products Sector.” Industrial Relations, vol. 35, pp. 374-399.

Lynch, Lisa M., editor, Training and the Private Sector: International Comparisons. Chicago: University of Chicago Press, 1994.

Lynch, Lisa M. and Sandra E. Black. 1998. "Beyond the Incidence of Training: Evidence from a National Employers' Survey", Industrial and Labor Relations Review, Oct. pp. $64-81$.

Milgrom, Paul and John Roberts. 1995. "Complementarities and Fit: Strategy, structure and organizational change in manufacturing." Journal of Accounting and Economics, vol. 19. pp. 179-208.

Nickell, Stephen, Daphne Nicolitsas and Malcolm Patterson. 2001. "Does Doing Badly Encourage Management Innovation?" Oxford Bulletin of Economics and Statistics, vol. 63, 2001.

Osterman, Paul. 1994. "How Common is Workplace Transformation and Who Adopts it?” Industrial and Labor Relations Review, January.

Pil, Frits and John Paul MacDuffie. 1996. "The Adoption of High Involvement Work Practices." Industrial Relations. 35:3, pp. 423-55.

Yellen, Janet. 2005. "Prospects for the U.S. Economy", Presentation to the University of California at Berkeley Boalt School Alumni San Francisco, California and available at http://www.frbsf.org/news/speeches/2005/050302.pdf 


\section{Data Appendix}

Shared rewards: Does your establishment contribute towards stock options or profit sharing?

Job Rotation: Job rotation refers to a work design system that allows employees to rotate between different jobs. What percent of, or how many non-managerial and nonsupervisory employees are currently involved in job rotation?

Production worker formal training: Formal training includes all types of training activities that have a predefined objective as opposed to informal on-the-job training. Examples of structured or formal training include seminars, lectures, workshops, audiovisual presentations, apprenticeship, and structured on-the-job learning. What percent of, or how many, production workers received formal training last year?

Workers meeting regularly: What percent of, or how many, non-managerial and nonsupervisory employees are involved in regularly scheduled meetings to discuss workplace issues?

Self-managed teams: Self managed teams have some degree of responsibility and discretion over such decisions as methods of work, tasks schedules, assignment of members to different tasks, and feedback about group performance. What percent of, or how many, non-managerial and non-supervisory employees are currently involved in self-managed teams?

Reengineering: Did this establishment undergo any re-engineering over the past three years?

For Manufacturing Establishments Only:

Using the U.S. Census Bureau's Longitudinal Research Database - average annual operating profit between 1987-1992 or 1990-1995; average annual investment per worker 1987-1992 or 1990-1995. Operating profit is calculated as total revenue - (labor + materials costs). 
Table 1: Incidence and Extent of Organizational Innovation (weighted Means):

\section{Practice}

Incidence ( $\%$ of establishments that have this):

Production Worker Training

Production Workers meeting regularly

Workers in self-managed teams

Job Rotation

Reengineering since 1994

Extent (\% of workers):

Production Worker Training

Production Workers meeting regularly

Workers in Self-managed teams

Job Rotation
Manufacturing Non-Manufacturing

1994

87.6

76.8

32.6

44.6

-

52.3

40.2

11.9

17.2
$1997 \quad 1994$

$\begin{array}{ll}76.6 & 80.9\end{array}$

74.2
31.7

$31.7 \quad 32.7$

$49.6 \quad 48.0$

12.3

51.8

52.8

16.7

23.7
1997

85.8

72.6

28.0

39.8

9.0

66.6

57.3

13.2

20.0

Table 2: Percentage of businesses that increased, decreased or left unchanged investments in Organizational Innovation 1994-1997 (Unweighted)

\section{Practice}

Extent (\% of workers):

Production Worker Training

Production Workers meeting regularly

Workers in Self-managed teams

Job Rotation
Manufacturing

up down unchanged

$42 \% \quad 35 \%$

37

26

$33 \quad 25$
Non-Manufacturing

up down unchanged

$61 \% \quad 21 \% \quad 17 \%$

$\begin{array}{lll}41 & 22 & 37\end{array}$

$\begin{array}{lll}19 & 19 & 62\end{array}$

$\begin{array}{lll}26 & 15 & 59\end{array}$


Figure 1: Extent and Diffusion of Organizational Innovation (1997 Weighted Data)

Non-Manufacturing
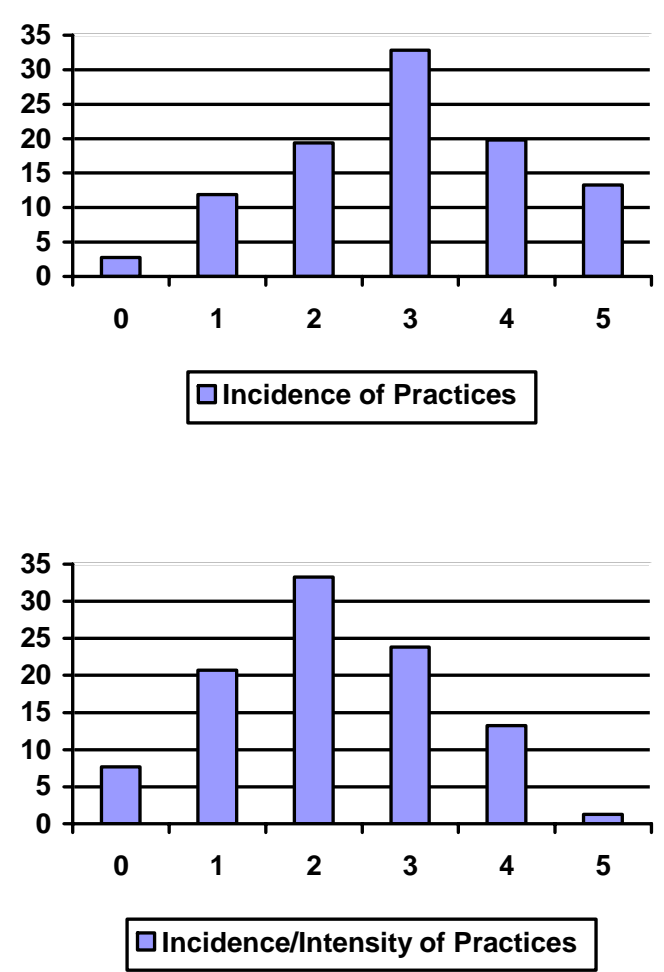

Manufacturing
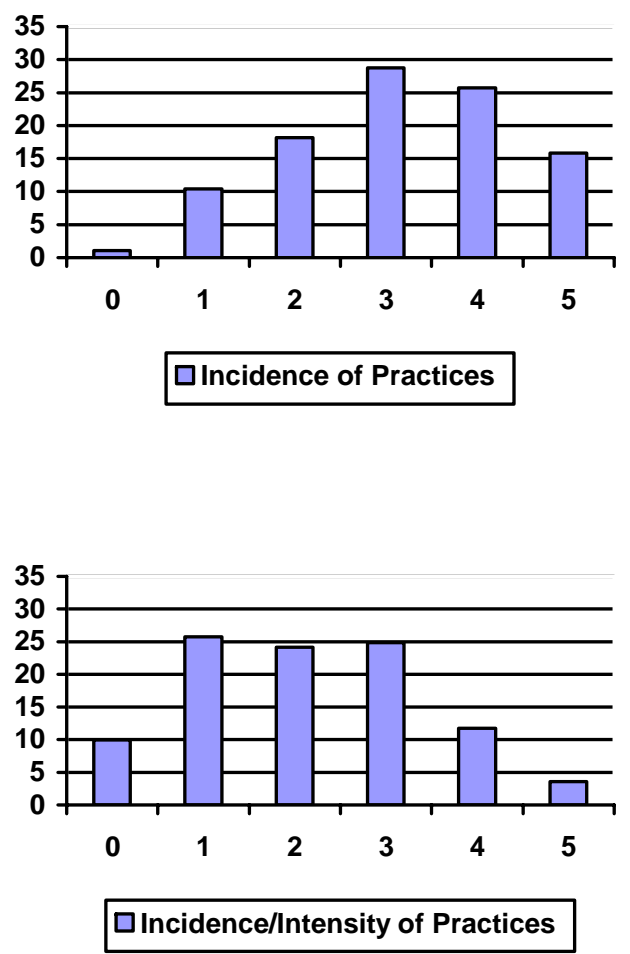
Table 3: Probability of Having a Specific Innovation: Manufacturing*

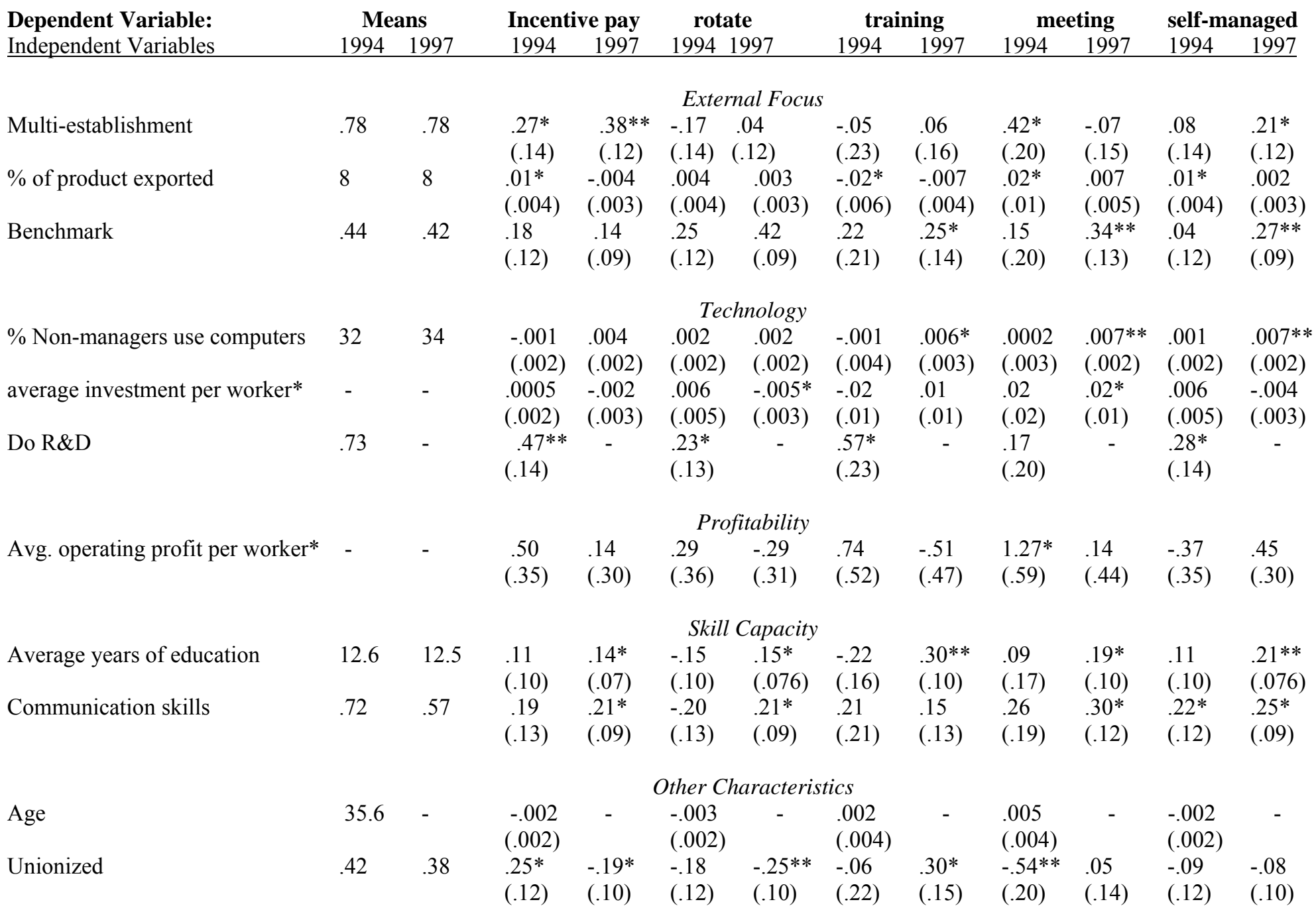




\begin{tabular}{|c|c|c|c|c|c|c|c|c|c|c|c|c|}
\hline Total workers & 775 & 571 & $\begin{array}{c}.0001^{*} \\
(5 e-05)\end{array}$ & $\begin{array}{l}.00014^{*} \\
(7 \mathrm{e}-07)\end{array}$ & $\begin{array}{r}.0002 * * \\
(7 e-05)\end{array}$ & $\begin{array}{c}9.9 \mathrm{e}-06 \\
(6 \mathrm{e}-05)\end{array}$ & $\begin{array}{l}.0003 * \\
(.00017\end{array}$ & $\begin{array}{c}.001 * * \\
(.0002)\end{array}$ & $\begin{array}{l}.0006^{*} \\
(.0002)\end{array}$ & $\begin{array}{l}.00002 \\
(.0001)\end{array}$ & $\begin{array}{l}.0002 * \\
.0000\end{array}$ & $\begin{array}{l}00003 \\
(.00006)\end{array}$ \\
\hline$\%$ production workers & 65.6 & 68.4 & $\begin{array}{l}.006 \\
(.006)\end{array}$ & $\begin{array}{l}.003 \\
(.005)\end{array}$ & $\begin{array}{l}.01 \sim \\
(.006)\end{array}$ & $\begin{array}{l}.01 * \\
(.005)\end{array}$ & $\begin{array}{l}.02 * \\
(.01)\end{array}$ & $\begin{array}{l}.02 * \\
(.01)\end{array}$ & $\begin{array}{l}.009 \\
(.01)\end{array}$ & $\begin{array}{l}.02 * * \\
(.01)\end{array}$ & $\begin{array}{l}.009 \\
(.006)\end{array}$ & $\begin{array}{l}.014^{*} \\
(.006)\end{array}$ \\
\hline$\%$ managers & 9.1 & 9.4 & $\begin{array}{l}.003 \\
(.01)\end{array}$ & $\begin{array}{l}-.003 \\
(.01)\end{array}$ & $\begin{array}{l}-.001 \\
(.011)\end{array}$ & $\begin{array}{l}-.0003 \\
(.008)\end{array}$ & $\begin{array}{l}.02 \\
(.02)\end{array}$ & $\begin{array}{l}.004 \\
(.01)\end{array}$ & $\begin{array}{l}-.01 \\
(.02)\end{array}$ & $\begin{array}{l}.01 \\
(.01)\end{array}$ & $\begin{array}{l}.002 \\
(.01)\end{array}$ & $\begin{array}{l}.008 \\
(.01)\end{array}$ \\
\hline$\%$ supervisors & 7.8 & 6.1 & $\begin{array}{l}-.002 \\
(.01)\end{array}$ & $\begin{array}{l}.005 \\
(.01)\end{array}$ & $\begin{array}{l}.007 \\
(.01)\end{array}$ & $\begin{array}{l}.027^{*} \\
(.012)\end{array}$ & $\begin{array}{l}.02 \\
(.02)\end{array}$ & $\begin{array}{l}.01 \\
(.02)\end{array}$ & $\begin{array}{l}.004 \\
(.03)\end{array}$ & $\begin{array}{l}.01 \\
(.02)\end{array}$ & $\begin{array}{l}-.003 \\
(.014)\end{array}$ & $\begin{array}{l}.02 \sim \\
(.012)\end{array}$ \\
\hline$\%$ technical workers & 7.7 & 6.6 & $\begin{array}{l}.006 \\
(.01)\end{array}$ & $\begin{array}{l}.004 \\
(.009)\end{array}$ & $\begin{array}{l}.02^{*} \\
(.01)\end{array}$ & $\begin{array}{l}.001 \\
(.01)\end{array}$ & $\begin{array}{l}.03 \\
(.02)\end{array}$ & $\begin{array}{l}.01 \\
(.01)\end{array}$ & $\begin{array}{l}.01 \\
(.02)\end{array}$ & $\begin{array}{l}.02^{*} \\
(.01)\end{array}$ & $\begin{array}{l}.02 * \\
(.01)\end{array}$ & $\begin{array}{l}.02 * \\
(.01)\end{array}$ \\
\hline Number of Establishments & 589 & 926 & 589 & 926 & 589 & 926 & 589 & 926 & 589 & 926 & 589 & 926 \\
\hline Pseudo R-squared & & & .11 & .06 & .11 & .09 & .23 & .16 & .23 & .13 & .08 & .09 \\
\hline
\end{tabular}

*Average investment per worker and average operating profit are for the period 1987-1992 for 1994 equations and for the period 1990-1995 for the 1997 equations. Also included in the estimation: 2-digit industry controls, \%employees female, \% employees minority, and the omitted occupational category is sales and clerical workers. Standard errors in ()$,{ }^{*}$ significant at $10 \%, * *$ significant at $1 \%, \sim$ almost significant at $10 \%$ 
Table 4: Diffusion of Specific Innovations: Manufacturing*

\begin{tabular}{|c|c|c|c|c|c|c|c|c|}
\hline \multirow{2}{*}{$\begin{array}{l}\text { Dependent Variable: } \\
\text { Independent Variables }\end{array}$} & \multicolumn{2}{|c|}{$\%$ rotate } & \multicolumn{2}{|c|}{$\%$ trained } & \multicolumn{2}{|c|}{ \% meeting } & \multicolumn{2}{|c|}{ \%self-managed } \\
\hline & 1994 & 1997 & 1994 & 1997 & 1994 & 1997 & 1994 & 1997 \\
\hline \multicolumn{9}{|c|}{ External Focus } \\
\hline \multirow[t]{2}{*}{ Multi-establishment } & .57 & -2.00 & 2.10 & 4.52 & 4.81 & -1.39 & 1.02 & .94 \\
\hline & $(3.06)$ & $(2.70)$ & $(3.89)$ & $(3.41)$ & $(4.07)$ & $(3.60)$ & $(2.81)$ & $(2.74)$ \\
\hline \multirow[t]{2}{*}{$\%$ of product exported } & .05 & .10 & .005 & -.06 & .04 & -.06 & .15 & -.03 \\
\hline & $(.09)$ & $(.07)$ & $(.12)$ & $(.09)$ & $(.12)$ & $(.09)$ & $(.09)$ & $(.07)$ \\
\hline \multirow[t]{2}{*}{ Benchmark } & $4.20^{*}$ & $6.38 * *$ & $10.62^{\prime}$ & $* 7.03 * *$ & $5.66^{*}$ & $7.03 * *$ & 2.23 & $8.17 * *$ \\
\hline & $(2.54)$ & $(2.12)$ & $(3.23)$ & $(2.68)$ & $(3.37)$ & $(2.68)$ & $(2.33)$ & $(2.15)$ \\
\hline \multicolumn{9}{|c|}{ Technology } \\
\hline \multirow[t]{2}{*}{$\%$ Non-managers use computers } & -.02 & .05 & -.02 & $.13 * *$ & $.11^{*}$ & $.11^{*}$ & .03 & $.14^{* *}$ \\
\hline & $(.04)$ & $(.04)$ & $(.06)$ & $(.046)$ & $(.06)$ & $(.05)$ & $(.04)$ & $(.04)$ \\
\hline \multirow[t]{2}{*}{ average investment per worker* } & $.16^{* *}$ & -.10 & $-.15 *$ & $.23 * *$ & $.14^{*}$ & .03 & $.14 * *$ & $-.11 *$ \\
\hline & $(.05)$ & $(.07)$ & $(.07)$ & $(.08)$ & $(.07)$ & $(.09)$ & $(.05)$ & $(.07)$ \\
\hline \multirow[t]{2}{*}{ Do R\&D } & .55 & - & $10.57^{\prime}$ & $*-$ & $14.66^{*}$ & $*-$ & $5.17 *$ & - \\
\hline & $(2.99)$ & & $(3.8)$ & & $(3.97)$ & & $(2.75)$ & \\
\hline \multicolumn{9}{|c|}{ Profitability } \\
\hline \multirow[t]{2}{*}{ average operating profit* } & 4.09 & -2.57 & -12.29 & 3.17 & \multirow{2}{*}{\multicolumn{2}{|c|}{$\begin{array}{l}25.88 * 11.04 \\
(10.12)(9.23)\end{array}$}} & 2.32 & $18.09 * *$ \\
\hline & $(7.62)$ & $(6.94)$ & $(9.70)$ & $(8.74)$ & & & $(7.00)$ & $(7.03)$ \\
\hline \multicolumn{9}{|c|}{ Skill Capacity } \\
\hline \multirow[t]{2}{*}{ Average years of education } & -2.60 & $3.46^{*}$ & -1.47 & 1.06 & -.35 & $6.19 * *$ & .38 & $3.72 *$ \\
\hline & $(2.15)$ & $(1.74)$ & $(2.73)$ & $(2.19)$ & $(2.86)$ & $(2.31)$ & $(1.97)$ & $(1.76)$ \\
\hline \multirow[t]{2}{*}{ Communication skills } & .64 & $5.70 * *$ & -1.08 & $5.97 *$ & $6.98^{*}$ & $10.26 * *$ & $4.70^{*}$ & $4.39 *$ \\
\hline & $(2.74)$ & $(2.08)$ & $(3.49)$ & $(2.62)$ & $(3.64)$ & $(2.76)$ & $(2.52)$ & $(2.10)$ \\
\hline
\end{tabular}


Age

Unionized

Total workers (00’s)

$\%$ production workers

$\%$ managers

$\%$ supervisors

$\%$ technical workers

Number of Establishments

Adjusted R-squared

\begin{tabular}{|c|c|c|c|c|c|c|c|}
\hline \multicolumn{8}{|c|}{ Other Characteristics } \\
\hline-.06 & - & $-.16^{*}$ & - & -.01 & - & $-.10 *$ & - \\
\hline$(.05)$ & & $(.06)$ & & $(.07)$ & & $(.05)$ & \\
\hline$-7.77 *$ & $*-6.09 * *$ & -4.19 & 3.23 & -10.95 & $*-7.75 * *$ & $-6.27^{*}$ & $*-9.32 * *$ \\
\hline$(2.70)$ & $(2.27)$ & $(3.44)$ & $(2.86)$ & $(3.59)$ & $(3.02)$ & $(2.49)$ & $(2.30)$ \\
\hline .001 & $-.0035^{*}$ & -.000 & .0006 & .001 & -.002 & -.0002 & -.0023 \\
\hline$(.001)($ & $.001)$ & $(.001)$ & $(.002)$ & $(.002)$ & $(.002)$ & $(.001)$ & $(.0014)$ \\
\hline $.28 *$ & $.70 * *$ & .30 & .28 & $.41 *$ & $.56^{* *}$ & .11 & $.37 * *$ \\
\hline$(.14)$ & $(.13)$ & $(.17)$ & $(.16)$ & $(.18)$ & $(.17)$ & $(.13)$ & $(.13)$ \\
\hline-.08 & $.43^{*}$ & $.56^{*}$ & $.48^{*}$ & .31 & .20 & -.02 & $.34 *$ \\
\hline$(.24)$ & $(.19)$ & $(.30)$ & $(.24)$ & $(.31)$ & $(.26)$ & $(.22)$ & $(.20)$ \\
\hline-.08 & $.61 *$ & $.65^{*}$ & .53 & -.14 & .50 & -.29 & -.05 \\
\hline$(.31)$ & $(.30)$ & $(.39)$ & $(.35)$ & $(.41)$ & $(.37)$ & $(.28)$ & $(.28)$ \\
\hline $.37 *$ & .18 & .57 & .39 & $.52 *$ & $.45^{*}$ & .08 & .30 \\
\hline$(.21)$ & $(.20)$ & $(.27)$ & $(.25)$ & $(.28)$ & $(.26)$ & $(.20)$ & $(.20)$ \\
\hline 589 & 926 & 589 & 926 & 589 & 926 & 589 & 926 \\
\hline .10 & .11 & .07 & .07 & .14 & .07 & .06 & .10 \\
\hline
\end{tabular}

*Average investment per worker and average operating profit are for the period 1987-1992 for 1994 equations and for the period 1990-1995 for the 1997 equations. Also included in the estimation: 2-digit industry controls, \% employees female, \% employees minority, and the omitted occupational category is sales and clerical workers. Standard errors in (), * significant at $10 \%$, ** significant at $1 \%, \sim$ almost significant at $10 \%$ 


\section{Table 5: Extent of Organizational Innovation: Manufacturing*}

\begin{tabular}{|c|c|c|c|c|c|c|c|}
\hline Dependent Variable: & -engineering & Count & of Practices & Diffusi & ion Count & Index & of Practices \\
\hline Independent Variables: & 1997 & 1994 & 1997 & 1994 & 1997 & 1994 & 1997 \\
\hline & & & External Foc & & & & \\
\hline Multi-establishment & $.27 *$ & .17 & $.26 * *$ & $.29 * *$ & $.22 *$ & $.17^{*}$ & .08 \\
\hline & $(.12)$ & $(.11)$ & $(.09)$ & $(.11)$ & $(.09)$ & $(.10)$ & $(.09)$ \\
\hline$\%$ of product exported & -.001 & $.008^{*}$ & .0002 & $.007^{*}$ & .0007 & $.006 *$ & -.0001 \\
\hline & $(.003)$ & $(.003)$ & $(.002)$ & $(.003)$ & $(.002)$ & $(.003)$ & $(.002)$ \\
\hline Benchmark & $.40 * *$ & $.27 * *$ & $.40 * *$ & $.35 * *$ & $.28 * *$ & $.29 * *$ & $.29 * *$ \\
\hline & $(.09)$ & $(.09)$ & $(.07)$ & $(.09)$ & $(.07)$ & $(.09)$ & $(.07)$ \\
\hline & & & Technology & & & & \\
\hline$\%$ Non-managers use computers & $.004 *$ & .002 & $.007 * *$ & .002 & $.005 * *$ & .001 & $.005 * *$ \\
\hline & $(.002)$ & $(.002)$ & $(.001)$ & $(.002)$ & $(.001)$ & $(.001)$ & $(.001)$ \\
\hline average investment per worker* & .001 & .002 & -.003 & $.004 *$ & -.001 & $.005 * *$ & -.0002 \\
\hline & $(.003)$ & $(.002)$ & $(.002)$ & $(.002)$ & $(.002)$ & $(.002)$ & $(.002)$ \\
\hline & & & Profitability & & & & \\
\hline average operating profit per worker* & $.53 *$ & $.49 *$ & .04 & $.47 *$ & $.42 *$ & $.44^{*}$ & $.36^{*}$ \\
\hline & $(.30)$ & $(.28)$ & $(.24)$ & $(.28)$ & $(.24)$ & $(.26)$ & $(.22)$ \\
\hline & & & Skill Capacit & & & & \\
\hline Average years of education & .03 & .006 & $.26 * *$ & -.05 & $.22 * *$ & -.01 & $.18 * *$ \\
\hline & $(.07)$ & $(.08)$ & $(.06)$ & $(.08)$ & $(.06)$ & $(.07)$ & $(.06)$ \\
\hline Communication skills & $.19 *$ & .15 & $.31 * *$ & $.19 *$ & $.23 * *$ & $.20 *$ & $.32 * *$ \\
\hline & $(.09)$ & $(.10)$ & $(.07)$ & $(.10)$ & $(.07)$ & $(.09)$ & $(.06)$ \\
\hline & & ther Estc & ablishment Ch & aracteris & stics & & \\
\hline Unionized & .006 & -.07 & $-.14 *$ & $-.28 * *$ & $-.30 * *$ & $-.32 * *$ & $-.26 * *$ \\
\hline & $(.10)$ & $(.09)$ & $(.08)$ & $(.09)$ & $(.08)$ & $(.09)$ & $(.07)$ \\
\hline
\end{tabular}




\begin{tabular}{|c|c|c|c|c|}
\hline Total workers & $\begin{array}{l}.001 \\
(.001)\end{array}$ & $\begin{array}{l}.0002 * * .0001 * \\
(.00005)(.00005)\end{array}$ & $\begin{array}{l}.0001-.00004 \\
(.00004)(.00005)\end{array}$ & $\begin{array}{l}.00004-.00006 \\
(.00004)(.00004)\end{array}$ \\
\hline \multirow[t]{2}{*}{$\%$ production workers } & $.28 *$ & $.015 * * .017 * *$ & $.016 * * .02 * *$ & $.014 * * .02 * *$ \\
\hline & $(.14)$ & $(.005)(.004)$ & $(.005)(.004)$ & $(.005)(.004)$ \\
\hline \multirow[t]{2}{*}{$\%$ managers } & -.08 & $.006 \quad .005$ & $.01 \quad .01 *$ & $.007 \quad .015^{*}$ \\
\hline & $(.24)$ & $(.009)(.007)$ & $(.008)(.0067)$ & $(.008)(.006)$ \\
\hline \multirow[t]{2}{*}{$\%$ supervisors } & -.08 & $.006 \quad .019^{*}$ & $-.003 \quad .01$ & $-.005 \quad .016^{*}$ \\
\hline & $(.31)$ & $(.01) \quad(.01)$ & $(.011)(.01)$ & $(.01) \quad(.009)$ \\
\hline \multirow[t]{2}{*}{$\%$ technical workers } & $.37 *$ & $.03 * * .014 *$ & $.023 * * .015 *$ & $.029 * * .01 *$ \\
\hline & $(.21)$ & $(.008)(.007)$ & $(.008)(.007)$ & $(.007)(.006)$ \\
\hline Number of Establishments & 589 & 589 & 926 & 926 \\
\hline Pseudo R-squared & .10 & .07 & .07 & \\
\hline Adjusted R-squared & & & & .15 \\
\hline
\end{tabular}

*Average investment per worker and average operating profit are for the period 1987-1992 for 1994 equations and for the period 1990-1995 for the 1997 equations. Also included in the estimation: 2-digit industry controls, \% employees female, \% employees minority, and the omitted occupational category is sales and clerical workers. Standard errors in (), * significant at $10 \%, * *$ significant at $1 \%, \sim$ almost significant at $10 \%$. Count does not include re-engineering. 
Table 6: Organizational Innovation: Panel Results for Manufacturing 1994-1997* ( N=191)

Dependent Variable:

Independent Variables

$\Delta$ Multi-establishment

$\Delta \%$ of product exported

$\Delta$ Benchmark

$\Delta \%$ Non-managers use compute
$\Delta$ average investment per work
$\Delta$ average operating profit*
$\Delta$ Average years of education
$\Delta$ Communication skills

$\Delta$ Unionized

$\Delta$ Total workers (00’s)

$\Delta \%$ production workers

$\Delta \%$ managers

$\Delta \%$ supervisors

$\Delta \%$ technical workers

1994 Values

Multi-establishment

Share of product exported

Benchmark

$\%$ Non-managers use computers
$\Delta$ Count

Eq. 1 Eq. 2 External Focus

$.21 * .43 *$

(.12) (.18)

$\begin{array}{lll}-.004 & -.003\end{array}$

(.004) (.005)

$\begin{array}{ll}.03 & -.10\end{array}$

(.12) (.18)

Technology

$$
\begin{array}{ll}
.001 & .006^{*} \\
(.002) & (.003) \\
.003 & .01
\end{array}
$$

(.01) (.01)

Profitability

$1.02 \quad 1.21$

(.99) (1.08)

Skill Capacity

$.05 \quad-.008$

(.11) (.16)

$.21 * .43 *$

(.12) (.18)

Other Characteristics

$\begin{array}{llll}.76 & .03 & -.01 & .91 \\ (.74) & (.80) & (0.01) & (1.17) \\ .0005^{* *} .0008^{* *} & -.0003 & -1.05 \mathrm{e}-06 \\ (.0002) & (.0003) & (1.43) & .0004 \\ -.0004 & -.009 & -.013 & -.02 \\ (.009) & (.01) & (1.21) & (0.01) \\ .01 & .004 & .004 & -.001 \\ (.01) & (.02) & (0.27) & (.03) \\ .005 & -.05 * & -.02 & -.07 \\ (.02) & (.02) & (0.97) & (.04) \\ .005 & -.002 & -.017 & -.01 \\ (.01) & (.01) & (1.17) & (0.02) \\ & & & \\ - & -.69 * & - & .92 * \\ & (.29) & & (0.41) \\ - & -.015 * & - & -.009 \\ & (.007) & & (0.01) \\ - & -.23 & - & .32 \\ & (.24) & & (.32) \\ - & .007 * & - & .001 \\ & (.004) & & (0.005)\end{array}$

Reengineer

Eq. 3 Eq. 4

$\begin{array}{ll}-.06 \quad .67 \\ -(.26) & (.46)\end{array}$

(.26) (.46)

$.02 * \quad .02 *$

(.007) (.009)

$.16 \quad .39^{*}$

(.15) (.24)

$.003 \quad .002$

(.003) (.004)

$.03 \quad .04 *$

(1.43) (0.02)

$\begin{array}{ll}-.08 & -.17\end{array}$

(1.28) (1.56)

$\begin{array}{ll}-.24 & -.13\end{array}$

(1.62) (0.24)

$.29 * \quad .60 *$

(1.91) (0.25)

$\begin{array}{ll}-.01 \quad .91 \\ -0.01) & (1.17\end{array}$

(0.01) (1.17)

$-.0003-1.05 \mathrm{e}-06$

(1.43) .0004

$\begin{array}{ll}-.013 & -.02\end{array}$

(1.21) (0.01)

$\begin{array}{ll}.004 & -.001\end{array}$

$(0.27)(.03)$

$\begin{array}{ll}-.02 & -.07\end{array}$

$(0.97)(.04)$

$\begin{array}{ll}-.017 & -.01\end{array}$

.92

(0.41)

$-.009$

.32

.001

(0.005) 


\begin{tabular}{|c|c|c|c|c|}
\hline average investment per worker & - & $\begin{array}{l}-.003 \\
(.01)\end{array}$ & - & $\begin{array}{l}-.003 \\
(0.02)\end{array}$ \\
\hline Do R\&D & - & $\begin{array}{l}-.29 \\
(.20)\end{array}$ & - & $\begin{array}{l}-.33 \\
(0.29)\end{array}$ \\
\hline average operating profit & - & $\begin{array}{l}-1.79^{*} \\
(.56)\end{array}$ & - & $\begin{array}{l}1.14 \\
(0.85)\end{array}$ \\
\hline Average years of education & - & $\begin{array}{l}-.15 \\
(.20)\end{array}$ & - & $\begin{array}{l}.51^{*} \\
(0.30)\end{array}$ \\
\hline Communication skills & - & $\begin{array}{l}.61 * * \\
(0.25)\end{array}$ & - & $\begin{array}{l}.46 \\
(0.34)\end{array}$ \\
\hline Age & & $\begin{array}{l}.005 \\
(.004)\end{array}$ & - & $\begin{array}{l}-.006 \\
(.005)\end{array}$ \\
\hline Unionized & - & $\begin{array}{l}-.24 \\
(0.19)\end{array}$ & - & $\begin{array}{l}-.27 \\
(0.28)\end{array}$ \\
\hline Total workers (00’s) & - & $\begin{array}{l}.0001 \\
(0.0001)\end{array}$ & - & $\begin{array}{l}.00006 \\
(.0002)\end{array}$ \\
\hline$\%$ production workers & - & $\begin{array}{l}-.01 \\
(0.01)\end{array}$ & - & $\begin{array}{l}.009 \\
(0.02)\end{array}$ \\
\hline$\%$ managers & - & $\begin{array}{l}-.03 \\
(0.02)\end{array}$ & - & $\begin{array}{l}.004 \\
(0.04)\end{array}$ \\
\hline$\%$ supervisors & - & $\begin{array}{l}-0.5^{*} \\
(0.03)\end{array}$ & - & $\begin{array}{l}-.06 \\
(0.04)\end{array}$ \\
\hline$\%$ technical workers & - & $\begin{array}{l}.005 \\
(0.02)\end{array}$ & - & $\begin{array}{l}0.04 \\
(0.03)\end{array}$ \\
\hline Pseudo R-squared & .08 & .10 & .11 & .27 \\
\hline
\end{tabular}


Table 7: Probability of Having a Specific Innovation: Non-Manufacturing*

\begin{tabular}{|c|c|c|c|c|c|c|c|c|c|c|c|c|}
\hline \multirow{2}{*}{$\begin{array}{l}\text { Dependent Variable: } \\
\text { Independent Variables }\end{array}$} & \multirow{2}{*}{\multicolumn{2}{|c|}{$\begin{array}{c}\text { Means } \\
1994 \quad 1997 \\
\end{array}$}} & \multicolumn{2}{|c|}{ Shared rewards } & \multicolumn{2}{|c|}{ Rotate } & \multicolumn{2}{|c|}{ Train } & \multicolumn{2}{|c|}{ Workers Meet } & \multicolumn{2}{|c|}{ Self-managed } \\
\hline & & & 1994 & 1997 & 1994 & 1997 & 1994 & 1997 & 1994 & 1997 & 1994 & 1997 \\
\hline \multicolumn{13}{|c|}{ External Focus } \\
\hline Multi-establishment & .70 & .59 & $\begin{array}{l}.71 * * \\
(.15)\end{array}$ & $\begin{array}{l}.57^{* *} \\
(.11)\end{array}$ & $\begin{array}{r}.02 \\
(11)\end{array}$ & $\begin{array}{c}.08 \\
(.11)\end{array}$ & $\begin{array}{l}.09 \\
(.13)\end{array}$ & $\begin{array}{l}.17 \\
(.17)\end{array}$ & $\begin{array}{l}.02 \\
(.14)\end{array}$ & $\begin{array}{l}.15 \\
(.15)\end{array}$ & $\begin{array}{l}.02 \\
(.12)\end{array}$ & $\begin{array}{l}-.002 \\
(.11)\end{array}$ \\
\hline Benchmark & .35 & .36 & $\begin{array}{l}.25^{*} \\
(.12)\end{array}$ & $\begin{array}{l}.04 \\
(.11)\end{array}$ & $\begin{array}{l}.24 * \\
(.11)\end{array}$ & $\begin{array}{l}.10 \\
(.11)\end{array}$ & $\begin{array}{l}.31 \\
(.14)\end{array}$ & $\begin{array}{l}.27 \\
(.18)\end{array}$ & $\begin{array}{l}.43^{* *} \\
(.16)\end{array}$ & $\begin{array}{l}.33^{*} \\
(.16)\end{array}$ & $\begin{array}{l}.37 \\
(.11)\end{array}$ & $\begin{array}{l}.40 \\
(.11)\end{array}$ \\
\hline \multicolumn{13}{|c|}{ Technology } \\
\hline$\%$ Non-managers use computers & .53 & .68 & $\begin{array}{l}.002 \\
(.002)\end{array}$ & $\begin{array}{l}.0018 \\
(.0015)\end{array}$ & $\begin{array}{l}.001 \\
(.001)\end{array}$ & $\begin{array}{l}.0018 \\
(.0015)\end{array}$ & $\begin{array}{l}.006^{*} \\
(.0018\end{array}$ & $\begin{array}{l}* .003 \sim \\
(.002)\end{array}$ & $\begin{array}{l}.0002 \\
(.002)\end{array}$ & $\begin{array}{l}.0002 \\
(.002)\end{array}$ & $\begin{array}{l}-.0002 \\
(.002)\end{array}$ & $\begin{array}{l}-.0005 \\
(.002)\end{array}$ \\
\hline Do R\&D & .34 & - & $\begin{array}{l}.74 * * \\
(.12)\end{array}$ & - & $\begin{array}{l}.15 \\
(.11)\end{array}$ & - & $\begin{array}{l}.17 \\
(.15)\end{array}$ & - & $\begin{array}{l}.49 \\
(.16)\end{array}$ & - & $\begin{array}{l}.30 * * \\
(.12)\end{array}$ & - \\
\hline \multicolumn{13}{|c|}{ Skill Capacity } \\
\hline Average years of education & 13.12 & 13.18 & $\begin{array}{l}.04 \\
(.06)\end{array}$ & $\begin{array}{l}.16^{* *} \\
(.05)\end{array}$ & $\begin{array}{l}.03 \\
(.05)\end{array}$ & $\begin{array}{l}-.01 \\
(.05)\end{array}$ & $\begin{array}{l}.06 \\
(.06)\end{array}$ & $\begin{array}{l}.10 \\
(.08)\end{array}$ & $\begin{array}{l}.05 \\
(.07)\end{array}$ & $\begin{array}{l}.17^{*} \\
(.08)\end{array}$ & $\begin{array}{l}.01 \\
(.05)\end{array}$ & $\begin{array}{l}.22 * * \\
(.05)\end{array}$ \\
\hline Communication skills & .83 & .82 & $\begin{array}{c}.20 \\
(.18)\end{array}$ & $\begin{array}{l}.21 \\
(.15)\end{array}$ & $\begin{array}{l}-.10 \\
(.14)\end{array}$ & $\begin{array}{l}.24^{*} \\
(.14)\end{array}$ & $\begin{array}{l}.07 \\
(.16)\end{array}$ & $\begin{array}{l}-.21 \\
(.21)\end{array}$ & $\begin{array}{l}.22 \\
(.17)\end{array}$ & $\begin{array}{l}.10 \\
(.19)\end{array}$ & $\begin{array}{l}.05 \\
(.15)\end{array}$ & $\begin{array}{l}.15 \\
(.15)\end{array}$ \\
\hline \multicolumn{13}{|c|}{ Other Characteristics } \\
\hline Unionized & .23 & .19 & $\begin{array}{l}.34^{*} \\
(.15)\end{array}$ & $\begin{array}{l}-.05 \\
(.14)\end{array}$ & $\begin{array}{l}-.04 \\
(.13)\end{array}$ & $\begin{array}{l}-.04 \\
(.14)\end{array}$ & $\begin{array}{l}-.18 \\
(.15)\end{array}$ & $\begin{array}{l}.18 \\
(.21)\end{array}$ & $\begin{array}{l}.02 \\
(.17)\end{array}$ & $\begin{array}{l}-.08 \\
(.19)\end{array}$ & $\begin{array}{l}.01 \\
(.14)\end{array}$ & $\begin{array}{l}-.08 \\
(.14)\end{array}$ \\
\hline Age of establishment (years) & 23 & - & $\begin{array}{c}-.004 \\
(.003)\end{array}$ & ) & $\begin{array}{r}-.001 \\
(.002\end{array}$ & - & $\begin{array}{c}-.001 \\
(.003)\end{array}$ & - & $\begin{array}{r}-.0001 \\
(.003)\end{array}$ & - & $\begin{array}{l}-.003 \\
(.003)\end{array}$ & - \\
\hline Total workers (00’s) & 497 & 415 & $\begin{array}{l}.00008 \\
(5 \mathrm{e}-05)\end{array}$ & $\begin{array}{l}3 * .00006 \\
(5 \mathrm{e}-05)\end{array}$ & $\begin{array}{l}6.66 \mathrm{e}-0 \\
(3 \mathrm{e}-05)\end{array}$ & $\begin{array}{l}(5 \mathrm{e}-000)^{*} \\
(5 \mathrm{e})\end{array}$ & $\begin{array}{r}2 \mathrm{e}-05 \\
(5 \mathrm{e}-05)\end{array}$ & $\begin{array}{l}.00002 \\
(.0002)\end{array}$ & $\begin{array}{l}-1.9 \mathrm{e}-06 \\
(5 \mathrm{e}-05)\end{array}$ & $\begin{array}{l}.00003 \\
(.0001)\end{array}$ & $\begin{array}{l}6.7 \mathrm{e}-06 \\
(.00003)\end{array}$ & $\begin{array}{l}5 \mathrm{e}-05 \\
(5 \mathrm{e}-05)\end{array}$ \\
\hline
\end{tabular}




\begin{tabular}{|c|c|c|c|c|c|c|c|c|c|c|c|c|}
\hline$\%$ production workers & 54 & 51 & $\begin{array}{c}.0005 \\
(.0043)\end{array}$ & $\begin{array}{l}.006 \\
(.004)\end{array}$ & $\begin{array}{l}-.004 \\
(.004)\end{array}$ & $\begin{array}{c}.002 \\
(.004)\end{array}$ & $\begin{array}{l}-.008 \\
(.005)\end{array}$ & $\begin{array}{l}-.001 \\
(.006)\end{array}$ & $\begin{array}{l}-.002 \\
(.004)\end{array}$ & $\begin{array}{l}.003 \\
(.005)\end{array}$ & $\begin{array}{l}.004 \\
(.004)\end{array}$ & $\begin{array}{l}.01 * * \\
(.004)\end{array}$ \\
\hline$\%$ managers & 12 & 14 & $\begin{array}{l}-.0008 \\
(.0072)\end{array}$ & $\begin{array}{l}.001 \\
(.006)\end{array}$ & $\begin{array}{l}.001 \\
(.006)\end{array}$ & $\begin{array}{r}-.007 \\
(.006)\end{array}$ & $\begin{array}{l}.002 \\
(.009)\end{array}$ & $\begin{array}{l}-.02^{*} \\
(.009)\end{array}$ & $\begin{array}{l}(5 \mathrm{e}-05) \\
(.008)\end{array}$ & $\begin{array}{l}.007 \\
(.009)\end{array}$ & $\begin{array}{l}.006 \\
(.007)\end{array}$ & $\begin{array}{l}.004 \\
(.007)\end{array}$ \\
\hline$\%$ supervisors & 9 & 8 & $\begin{array}{c}-.0022 \\
(.0099)\end{array}$ & $\begin{array}{l}-.005 \\
(.009)\end{array}$ & $\begin{array}{l}.015 \\
(.009)\end{array}$ & $\begin{array}{l}.013 \\
(.009)\end{array}$ & $\begin{array}{l}.007 \\
(.01)\end{array}$ & $\begin{array}{l}-.007 \\
(.013)\end{array}$ & $\begin{array}{l}.012 \\
(.01)\end{array}$ & $\begin{array}{l}.05 * * \\
.01)\end{array}$ & $\begin{array}{l}.015^{*} \\
(.009)\end{array}$ & $\begin{array}{l}.009 \\
(.009)\end{array}$ \\
\hline$\%$ technical workers & 11 & 12 & $\begin{array}{r}.0058 \\
(.0049\end{array}$ & $\begin{array}{l}.006 \\
(.005)\end{array}$ & $\begin{array}{l}.008 \\
(.005)\end{array}$ & $\begin{array}{l}.01^{*} \\
(.004)\end{array}$ & $\begin{array}{l}-.009 \\
(.006)\end{array}$ & $\begin{array}{l}-.008 \\
(.008)\end{array}$ & $\begin{array}{r}-.0004 \\
(.006)\end{array}$ & $\begin{array}{l}.006 \\
(.007)\end{array}$ & $\begin{array}{l}.008 \\
(.005)\end{array}$ & $\begin{array}{l}.017^{*} \\
(.005)\end{array}$ \\
\hline Number of Establishments & 696 & 689 & 696 & 689 & 696 & 689 & 696 & 689 & 696 & 689 & 696 & 689 \\
\hline Pseudo R-squared & & & 0.22 & 0.12 & .05 & .06 & .14 & .15 & .11 & .12 & .07 & .08 \\
\hline
\end{tabular}

*Also included: 2-digit industry controls, \% employees female, \% employees minority, and the omitted occupational category is sales and clerical workers. Standard errors in ()$,{ }^{*}$ significant at $10 \%, * *$ significant at $1 \%, \sim$ almost significant at $10 \%$. 
Table 8: Diffusion of Specific Innovations: Non-Manufacturing*

Dependent Variable: \% rotate \% training

Independent Variables

$19941997 \quad 1994 \quad 1997$

\% meeting \% self-managed

Multi-establishment

External Focus

Multi-establishment

$\begin{array}{llll}-.23 & -1.27 & 1.59 & 3.76\end{array}$

$1994 \quad 1997 \quad 1994 \quad 1997$

Benchmark

(2.06) (2.35) (3.38) (3.04)

$\begin{array}{llll}.03 & -1.07 & 2.58 & 1.57\end{array}$

$\begin{array}{llll}3.48 & -2.40 & -1.61 & -6.56^{* *}\end{array}$

(1.96) $(2.34)$

(3.12) (3.04)

$\begin{array}{llll}(3.64) & (3.30) & (2.02) & (2.49)\end{array}$

$6.35^{*} \quad 1.74 \quad 1.46 \quad 3.57$

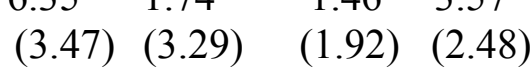

$\%$ Non-managers use computers

Technology

$\begin{array}{llllllll}.04 & .02 & .06 & .04 & .09 * & .05 & .001 & .016 \\ (0.03) & (.03) & (.04) & (.04) & (.05) & (.05) & (.027) & (.035) \\ 1.16 & - & 6.85 * & - & 7.69 * & - & 4.35^{*} & - \\ (2.05) & & (3.26) & & (3.62) & & (2.01) & \end{array}$

Do R\&D

Skill Capacity

Average years of education

$\begin{array}{clllllll}.55 & -1.72 & -1.98 & 1.48 & 3.38^{*} & -1.34 & .51 & 3.83 * * \\ (.92) & (1.14) & (1.47) & (1.48) & (1.63) & (1.60) & (.91) & (3.24) \\ .53 & 1.42 & .66 & 1.44 & -.43 & 5.68 & 6.08 * & 3.07 \\ (2.57) & (3.06) & (4.10) & (3.96) & (4.55) & (4.29) & (2.53) & (3.24)\end{array}$

Unionized

Other Characteristics

Age

Total workers (00’s)

$\begin{array}{cccccccc}-1.53 & .31 & -5.21 & 6.79 * & -9.40 * & -7.93 * & -.79 & 1.00 \\ (2.34) & (2.94) & (3.73) & (3.81) & (4.15) & (4.13) & (2.30) & (3.12) \\ -.10 * & - & .006 & - & -.13 * & - & -.09 * & - \\ (.04) & & (.07) & & (.077) & & (.04) & \\ -.001 & -.002 & -.002 * & -.003 * & -.0019 * & -.05 & -.0006 & -.0008 \\ (.001) & (.001) & (.001) & (.001) & (.001) & (.16) & (.0006) & (.001)\end{array}$




$\begin{array}{lllllllll}\text { \% production workers } & .07 & .08 & -.25^{*} & .16 & -.22^{*} & .29 * & .09 & .25^{* *} \\ & (.07) & (.08) & (.11) & (.11) & (.12) & (.17) & (.06) & (.09) \\ \text { \% managers } & .03 & -.09 & .12 * & .006 & -.25 & .53^{* *} & .19^{*} & .10 \\ & (.12) & (.13) & (.08) & (.17) & (.20) & (.186) & (.11) & (.14) \\ \text { \% supervisors } & .30^{*} & .20 & -.13 & .12 & .05 & .58^{*} & .02 & .21 \\ & (.15) & (.19) & (.24) & (.25) & (.26) & (.27) & (.14) & (.20) \\ \text { \% technical workers } & .09 & .01 & .13 & -.02 & -.35^{*} & .20 & .12 & .15 \\ & (.09) & (.10) & (.14) & (.13) & (.15) & (.14) & (.08) & (.11) \\ \text { Number of Establishments } & & & & & & & & \\ \text { Adjusted R-squared } & 696 & 689 & 696 & 689 & 696 & 689 & 696 & 689 \\ & .04 & .02 & .14 & .07 & .07 & .04 & .05 & .06\end{array}$

*Also included: 2-digit industry controls, \% employees female, \% employees minority, and the omitted occupational category is sales and clerical workers. Standard errors in ()$,{ }^{*}$ significant at $10 \%, * *$ significant at $1 \%, \sim$ almost significant at $10 \%$. 
Table 9: Extent of Organizational Innovation: Non-Manufacturing*

Dependent Variable: Re-engineering Count of Practices

Independent Variables

1997

19941997

Diffusion of Practices

Multi-establishment

Benchmark

$.22 *$
$(.11)$
$.55^{* *}$
$(.11)$

External Focus

$.29 * * \quad .28 * * \quad .32 * * \quad .14$

$(.09) \quad(.09) \quad(.09) \quad(.09)$

$.47 * * 28 * *$

$.21 * \quad .04$

(.09) (.09)

(.09) (.09)

Index of Practices

$\%$ Non-managers use computers

$$
001 \quad 32 * * \text { Technology }
$$

$.32 * * \quad .12$

(.12) $(.12)$

$.34 * * \quad .16$

(.13) (.12)

$.27 * * \quad .16$

(.10) (.03)

Average years of education

$.14 * *$
$(.05)$
.08
$(.15)$

Skills Capacity

Communication skills

$\begin{array}{ll}.06 & .17 * * \\ (.04) & (.04) \\ .15 & .175 \\ (.12) & (.11)\end{array}$

$$
.063 .09 *
$$

(.04) $(.04)$

$.09 \quad .27 *$

(.12) (.11)

$.19 * * \quad .007$

(.07) (.07)

$.19 * * * .07$

(.07) (.07)

(.12) (.11)

Other Characteristics

Unionized
Total workers
$\%$ production workers
$\%$ managers

.03

(.14)

.0001

(.0001)

.002

(.004)

.002

\begin{tabular}{|c|c|}
\hline-.04 & -.08 \\
\hline$(.11)$ & $(.11)$ \\
\hline $.00003-.00005$ & $-.00004-.00004$ \\
\hline$(.00003)(.0$ & $(.00003)(.00004)$ \\
\hline $.0002 \quad 0111$ & $-.00001 .0115^{* *}$ \\
\hline$(.0030)(.0031)$ & $(.0030)(.0031)$ \\
\hline $.0045 \quad .0044$ & $.0083 \quad 0044$ \\
\hline (.0053) (.0050) & $(.0053)(.0050)$ \\
\hline
\end{tabular}

(.006) $\begin{array}{ll}-.12 & -.009 \\ (.08) & (.09)\end{array}$

(.08) (.09)

$-.00005 *-.000055$

$(.00002)(.000035)$

$-.00005 .0097 * *$

$(.0023)(.0026)$

$.0064 \quad .0061$

$(.0041)(.0042)$ 


\begin{tabular}{|c|c|c|c|c|}
\hline$\%$ supervisors & $\begin{array}{l}-.001 \\
(.009)\end{array}$ & $\begin{array}{ll}.0128^{*} & .0087 \\
(.0067) & (.0073)\end{array}$ & $\begin{array}{ll}.0047 & .0087 \\
(.0068) & (.0073)\end{array}$ & $\begin{array}{l}.0033 .0113^{*} \\
(.0053)(.0061)\end{array}$ \\
\hline$\%$ technical workers & $\begin{array}{l}.007 \\
(.005)\end{array}$ & $\begin{array}{l}.0039 .0058 \\
(.0039)(.0039)\end{array}$ & $\begin{array}{ll}.0035 & .0058 \\
(.0040) & (.0039)\end{array}$ & $\begin{array}{l}.0026 \quad .0049 \\
(.0031)(.0032)\end{array}$ \\
\hline Number of Establishments & 696 & 696 & 696 & 696 \\
\hline $\begin{array}{l}\text { Pseudo R-squared } \\
\text { Adjusted R-squared }\end{array}$ & .11 & 0.05 & 0.05 & 0.12 \\
\hline
\end{tabular}

*Also included: 2-digit industry controls, \% employees female, \% employees minority, and the omitted occupational category is sales and clerical workers. Standard errors in ()$,{ }^{*}$ significant at $10 \%, * *$ significant at $1 \%, \sim$ almost significant at $10 \%$. Count does not include re-engineering. 